\title{
Respect and Respectability: The Treatment and Expectations of Fee-Paying Patients
}

In addition to providing class- and gender-appropriate occupations and amusements, proponents of moral therapy preached the benefits of maintaining harmonious surroundings. Yet, rising patient numbers and the consequent need for expanded facilities could greatly disrupt moral therapy. ${ }^{1}$ While moral therapy was used in Irish district asylums, the late nineteenth century has been characterised as an era of therapeutic pessimism for asylum doctors, due to the ever-rising and accumulating numbers of chronic or 'incurable' patients in the system. ${ }^{2}$ In modest-sized and large district asylums, financial and management problems impacted negatively on patient care. ${ }^{3}$

As a counterpoint, this chapter considers whether smaller, sometimes underfilled voluntary and private asylums were better equipped to provide moral therapy into the late nineteenth century, exploring the treatment and expectations of paying patients in the public, voluntary and private sectors. In her discussion of district asylums, Cox has argued that the language of social class and difference partly constructed the space between patients and staff. ${ }^{4}$ In the Scottish context, Beveridge has found that social class created tensions between patients and staff and between patients themselves. ${ }^{5}$ This chapter engages with these findings, by exploring the extent to which paying patients' expectations of asylum care were informed by their social status and class identity.

As Chap. 2 discussed, district asylum doctors and the lunacy inspectors were apprehensive about mixing paying and pauper patients in district asylums. Despite the Privy Council's decision to restrict paying patients to the same rules, regulations and treatment as the pauper

(C) The Author(s) 2018 207

A. Mauger, The Cost of Insanity in Nineteenth-Century

Ireland, Mental Health in Historical Perspective, https://doi.org/10.1007/978-3-319-65244-3_7 
patients, there was clearly an expectation of more class-appropriate care based on their social standing. This included receiving food to which they were accustomed and privacy from the pauper patients with whom they were compelled to reside. Despite concerns to limit jealousies between paying and pauper patients, differences in social class and status resulted in tensions. Many paying patients, anxious to reassert their respectability, expressed unease about their pauper cohabitants' social origins. ${ }^{6}$ Moreover, the social and political upheaval in Ireland resulted in religious and political divisions between patients. In contrast, the payment of higher maintenance fees at voluntary and private asylums translated into more class-appropriate accommodation and treatment, while the wealthiest patients could expect separate lodgings and special attendants. In these institutions, problems surrounding class, religion and politics were far less common, probably due to the segregation of patients from different social backgrounds.

As this chapter argues, while wealthier patients expected to be treated with 'respect', their carers anticipated certain standards of 'respectable' behaviour in return. This is evidenced in the case notes, where asylum doctors frequently commented on patients' violent behaviour, manners, dress and appearance. These considerations were influenced by not only the doctrines of moral therapy but also the physician's own understanding of class identity and social status. Notably, although voluntary and private asylums provided care tailored to social class, in line with other asylum populations, social decorum in these institutions was compromised by a surprisingly high level of violence among their more privileged clientele. ${ }^{7}$

\section{Expectations of CARE}

To assess patients' expectations of institutionalisation effectively, it is first necessary to contextualise their treatment. Studies of the treatment employed in Irish district asylums trace the decline of moral therapy throughout the nineteenth century and the eventual gloom that replaced this ideal towards the century's close. Resulting from the growing involvement of the medical community in district asylums, from the 1830s more 'medical' systems of treatment were adopted. ${ }^{8}$ Of the asylums studied here, Bloomfield had the strongest association with moral treatment because it was modelled on the York Retreat. From the outset, the committee which established Bloomfield 'solicited direct assistance' 
from the founder of the York Retreat, William Tuke, who was consulted on the construction of an addition to the existing premises and even asked to interview a candidate for superintendent.9 Although physical treatments, including leeching and the administering of emetics, were very much a part of Bloomfield's early regime of care, moral therapy came to play an increasing role. ${ }^{10}$ Relatively little is known of the early therapeutic regimes at Hampstead, although it is plausible that the asylum's founders, all medical men, shared similar optimism about the potential of medicine to 'cure' insanity, at least initially. This contrasts with the first district asylums, which were inspired by the ideology of moral treatment and managed by laymen who fashioned themselves as 'moral governors'. 11

By the late nineteenth century, some resident medical superintendents, including Richmond's Lalor (superintendent, 1857-1883) and his successor, Norman (superintendent, 1886-1908), took steps to reinforce the provision of moral treatment. By the 1890s, Norman, who unsuccessfully advocated the 'boarding out' of patients in the community, also increased occupational activity for patients and opened workshops for them. ${ }^{12}$ As we have seen, the grounds at Richmond were open to patients every day where sports, picnics and entertainments were organised. ${ }^{13}$ These principles in many ways reflected what had long been the norm in voluntary asylums like Bloomfield and Stewarts, or private asylums such as Hampstead House and Highfield House. Contrary to the overcrowded and unsanitary conditions in late nineteenth-century Richmond, smaller voluntary and private asylums benefited from lower patient numbers and more spacious arrangements. Obviously aware of this, Bloomfield's visiting physician, Dr. Valentine Duke, stated in 1862, that the advantages of moral treatment:

can be better experienced in a well conducted asylum of moderate extent, partaking in the domestic arrangements a good deal of a private family, than in some of those very large public establishments which number their patients by hundreds. ${ }^{14}$

Stewarts, meanwhile, was sometimes underfilled and reported space to accommodate more patients. In 1881, the asylum, which could accommodate up to 120 patients, contained only eighty-two. ${ }^{15}$

During the 1860s, Duke also made numerous recommendations for improved medical treatments, including the erection of a Turkish bath 
and procurement of seaside lodgings. Duke framed his suggestions with the medical benefits they would bestow, demonstrating a growing emphasis on physical rather than moral treatment. ${ }^{16}$ In this era, small tensions arose between the asylum's non-medical and medical staff over the most effective forms of treatment. When the visiting surgeon applied leeches to a patient's head, Bloomfield's house steward, Stanley wrote: 'the leeching made it appears to me, no improvement whatever in him'. ${ }^{17}$ The following day, when Duke gave 'four powders' to the patient and produced blisters on his temples, Stanley again protested 'but all have proved useless and he appears to be beyond the reach of human skill'. ${ }^{18}$ Stanley had his own views on what constituted useful therapies for male patients. He was a keen proponent of outdoor exercise and introduced 'football recreation', which he actively participated in almost every afternoon. ${ }^{19}$ Stanley also frequently remonstrated with elderly patients in a bid to encourage them to go out in the fresh air. Despite any tensions between Stanley and Duke, Bloomfield's managing committee took Duke's recommendations seriously. Stanley later reported that three of the male patients had taken Turkish baths, that 'they seem to have enjoyed them' and that one patient 'thinks they may likely benefit his health'. ${ }^{20}$ Meanwhile, lodgings were taken in the summer at the seaside town of Bray for some female patients 'whose state of health indicated the want of such a change'. The committee were impressed by these outcomes, reporting that 'the salutary result has satisfied us of its advantage', and patients continued to be sent to Bray throughout the nineteenth century. ${ }^{21}$

The blending of moral and physical principles of treatment at Bloomfield demonstrates the complexities of therapeutic programmes for the insane. Just as individual district asylums were influenced by the ideologies and character of the physicians who presided over them, ${ }^{22}$ voluntary and private asylum doctors had the authority to promote a change of regime. Overall, however, ever-rising patient numbers in district asylums such as Richmond frustrated the attempts of even the most innovative asylum physician, who was often powerless to treat anything more than physical illnesses. ${ }^{23}$

Treatment was also influenced by the amounts spent on care. In voluntary and private asylums, patients kept at the highest sums could expect larger, even separate, living quarters, higher quality clothing and a special attendant. As such, voluntary and private asylums tailored accommodation to suit patients from wealthy backgrounds. In the 
1890s, Stewarts patient, Isabella McE, a fifty-two-year-old widow who had previously been a patient at the Derry district asylum, was initially maintained at $£ 50$ per annum. While at Stewarts, she accused the RMS, Rainsford, 'daily of robbing her. Says I get millions sent for her, that hampers of wine and game come for her every morning which matron and I appropriate, that her food is poisoned \&c'. She was later 'much pleased' when her maintenance fees were raised and she was transferred to her own separate bedroom. ${ }^{24}$ In contrast, Beatrice Katherine Q., who accused Rainsford of 'having stolen her money and spent it on women', was removed to an ordinary room after her fees were reduced from $£ 100$ to $£ 60$ per annum, presumably after a shift in her financial circumstances. ${ }^{25}$ After John Charles B. became a Chancery patient, he was moved to a separate bedroom and dined in the 'better dining room'. ${ }^{26}$

The same applied at Bloomfield. In the 1890s, when William R. began to masturbate publicly, he was repeatedly restrained in a straitjacket. Several attempts were made 'to do without his jacket' including the application of 'a lighter jacket with straps round arms' but this did not restrain him from masturbating and a few months later he began 'taking his clothes off on the grounds and exposing his person'. The following year he was still wearing the jacket when in the garden. On another trial without it, he began to throw stones over the garden wall and 'annoyed the neighbours'. A month later, the reporting physician commented:

He has been wearing his jacket while in the garden lately. Unless a man were constantly to stand by him it is not possible to check him suddenly exposing his person, or throwing stones ... over the wall and as he only pays a small sum per annum, we cannot give him a special attendant.

This suggests that had William been maintained at a higher sum, he might have been under the care of a special attendant rather than in restraints. William, who had been admitted to Bloomfield in 1850, was then maintained at $£ 31$ per annum. There is no record of his maintenance fee being raised but, by the 1890s, the 'small sum' paid towards his maintenance probably put him at the lower end of the fee scale at Bloomfield. ${ }^{27}$

In district asylums, paying patients' experiences were shaped by the Privy Council rules as they were subject to the same treatment as pauper patients. This meant that the amount paid towards patients' maintenance 
had very little impact on their treatment. Nonetheless, some paying patients and their relatives and friends expected superior treatment, particularly at Richmond. According to one medical officer, Thomas D., a pensioner patient from the Dublin Metropolitan Police was 'constantly asking for special extras ... there is a general tendency to the expression of a sense of superiority'. ${ }^{28}$ Families and friends could also intervene. When Daniel McK's son, who contributed $£ 26$ per annum for his father's maintenance, wrote to the board of governors 'requesting that he may be allowed to wear his own clothes', the board refused, insisting that Daniel should 'wear clothes of institution'. ${ }^{29}$ A family friend of another paying patient, Daniel N., stressed that the patient was 'respectably connected' and requested 'that he be separated from ordinary lunatics and no expense spared for his benefit'. ${ }^{30}$

Notwithstanding these expectations, the lunacy inspectors strictly upheld the Privy Council's guidelines. In 1891, the Office of Lunatic Asylums wrote to Ennis asylum:

Referring to a passage in the Auditors report in which he states that there are three patients in the asylum whose friends contribute in excess of the average cost, and receive for such payment more indulgences as to Food and clothing than other cases - I am directed by the Inspectors to request you will report the facts of these cases to them. ${ }^{31}$

While the asylum board's response is not documented, a subsequent letter from the Office drew the board's attention to the Privy Council rules and to the auditor's report that had identified the problem. ${ }^{32}$ These letters indicate that the Office sought to guard against the preferential treatment of paying patients and did not tolerate it.

Dietary became a key area of difficulty in the treatment of paying patients in district asylums. In the nineteenth century, this was an important element of asylum therapeutics and for most patients, the aim was to improve nutritional intake. ${ }^{33}$ Good feeding was considered essential for the recovery of mental health to a physically healthy body. ${ }^{34}$ This emulated the beliefs of the physician superintendent at the Royal Edinburgh Asylum, Dr. Thomas Clouston (1873-1908), that stoutness was conducive to mental health and his development of a 'Gospel of Fatness' which involved the feeding up of patients. ${ }^{35}$ In Ireland, the lunacy inspectors were keen that asylum dietaries resemble those of the patients outside the asylum, hoping that it would help them to acclimatise to asylum 
life. ${ }^{36}$ However, in keeping with the concerns expressed by a number of medical superintendents at the 1857-1858 commission, and later criticisms of the Trench commission (see Chap. 2), several paying patients, especially those from more affluent backgrounds and accustomed to a better standard of living, were given an inferior diet to what they ate at home. In fact, there is no record that paying patients in this study were given food other than the standard asylum dietary. The only extra reportedly supplied to paying patients was alcohol. Although often used for medicinal purposes, in Enniscorthy the prescription of alcohol appeared in a few cases to be more of a small indulgence on the part of the RMS. Anne J. would not eat but said she would drink some 'alter wine'. In an attempt to compromise, the RMS procured some port wine, but Anne refused to take it. Later on, it was noted that Anne 'likes a drop of punch' and she was given whiskey and later poitín. ${ }^{37}$ Similarly, when Teresa C. wished 'for a little bitter in evening', she was given ' $3 \mathrm{oz}$ of bitter extra'. ${ }^{38}$

Although some paying patients, such as Mary E. at Richmond, complimented the diet they were given - 'says ... she gets a beautiful dinner every day'-most paying patients' responses to their food were negative. ${ }^{39}$ Suggesting their unease at being given a pauper patient's dietary, paying patients complained about both the quality and quantity of the food they received. This is in direct contrast to patients at the Royal Edinburgh asylum, for whom the emphasis on hearty eating was a focus of resentment. ${ }^{40}$ At Richmond, Mary B., whose relatives paid over $£ 29$ per annum for her maintenance, was 'very dissatisfied with her dinner' and was later discharged to a private asylum. ${ }^{41}$ Frances N., whose maintenance was over $£ 24$ per annum, had previously been a patient at St Patrick's. While at Richmond, Frances was 'continually asking to be sent home, and complains bitterly of the arrangements, feeding ect [sic] in this place and compares her life now to the life of luxury she had before she came in'. ${ }^{42}$ John H., meanwhile, said that 'he is happy that his appetite is good but he does not get enough to eat'. ${ }^{43}$ At Enniscorthy, Anne J. had delusions that 'those around her mean to starve her'. ${ }^{44}$

Those who complained about the quantity of their meals were often characterised by the medical staff as greedy or having abnormally large appetites. At Richmond, Catherine C., who was contributing highly at $£ 24$ per annum, complained that: 
they don't give her potatoes as a right but of rice (she is greedy and grumbling at meals) ... Asked if she gets enough to eat says she sometimes only gets one cut of bread '\& that's not enough for Catherine C'! Says she ought to get two cups of tea, and one cup of milk.

The nurse reported that 'she has a terrible appetite and is always fighting about her food'. When Catherine informed a medical officer that 'they forgot to give her dinner yesterday, she got a piece of rotten plum pudding', he noted in brackets that 'she got meat as well' ${ }^{45}$ Although most of these complaints came from patients contributing high sums for their maintenance, this was not exclusively the case. Mary W.P., whose relatives contributed a moderate $£ 12$, also 'grumbles against the attendants for not giving enough to eat' and it was noted that she 'seems to have a very large appetite'. ${ }^{46}$

Some paying patients in Richmond requested additional food articles such as mutton and eggs. ${ }^{47}$ Edwina Matilda D. wrote to a relative, Pauline, imploring her to bring food:

It is dreadful - please bring clothes to me I am in great affliction. I am hungry for want of a chicken and grapes in much need of sympathy come as soon as you can I am as cold as a stone nearly ... come at once as I am cold and want to see you Pauline. I never was in such trouble in my life. ${ }^{48}$

In late nineteenth-century Dublin, articles like beef or mutton were a rare luxury for the poor and were generally reserved for the family breadwinner, while eggs were considered a luxury, because of their commercial value. Grapes and chicken were also less common delicacies and certainly did not feature at the tables of the impoverished. ${ }^{49}$ Paying patients in Richmond were therefore openly contesting the provision of more runof-the-mill foodstuffs. Whether as an assertion of their social standing or simply a longing for the more rich and varied mealtimes they had previously enjoyed, paying patients were clearly unimpressed with the dietary on offer. Little wonder, perhaps, that Enniscorthy paying patient, Francis $\mathrm{R}$., literally dreamt of a more varied dietary; at eleven o'clock one morning, he imagined that he had already eaten a dinner 'of salt herrings and potatoes'.50

At Enniscorthy, Drapes took account of the types of food paying patients consumed at home, suggesting he was mindful of the disparities in dietary customs. In 1897, Drapes noted that Maria C. 'took 
no breakfast but eat [sic] her dinner: would not take porridge though brother told me she eat [sic] it at home' ${ }^{51}$ The following year, when Margaret Sara K. refused her food and had to be tube fed, the nurse suggested that she was 'particular about her food and thinks she might get her to take some if she cooked it for her in division'. Drapes allowed this and the following week it was recorded she was 'taking her food better' ${ }^{52}$ Because the provision of dietary fell within the realm of medical treatment, resident medical superintendents retained control over whether relatives could supply additional food articles. Although not explicitly prohibited by the Privy Council rules, at Enniscorthy, relatives were not allowed to provide luxuries. In 1877, the RMS, Edmundson, wrote to one paying patient's daughter asking that she 'might please not bring Beef tea \&c. to your father as he is supplied with everything we deem fit for him here'. ${ }^{53}$ At Richmond, relatives could supply extras. Hesta W's mother and friends brought her food, although she refused to accept it, believing it was poison. ${ }^{54}$ Patrick C. refused 'very nearly all the food supplied by the asylum, but takes freely whatever his brothers bring or send him'. In this case, the patient declined to say why he refused the institution's food. ${ }^{55}$

The centrality of food within the case notes examined indicates the medical emphasis on good feeding as a facet of treatment. The frequency and similarity of patients' complaints recorded in the case notes, however, suggests that diet was one area where district asylum care did not meet paying patients' expectations. At Richmond, some campaigned for improved dietary standards. Walter J.H., formerly a staff sergeant in the army, wrote a letter to Norman after two of the other medical officers allegedly consented to his 'making some suggestions for the improvement of the management of this establishment'. He pointed out that:

the food as supplied to sick patients is not what it should be - Before I can draw up a good plan, I should require to see what facilities you have for cooking purposes - what arrangements are made to ensure cleanliness \& what is done to prevent waste of unconsumed food. It appears to me that under the present regime waste is inevitable. If Dr Reddington's invitation to me to attend a Board Meeting could be carried out, I am sure that you would profit by my presence. ${ }^{56}$

The validity of Walter's supposed invitation is questionable and there is no record of Walter actually attending board meetings. Nonetheless, 
Walter's letter suggests that some paying patients perceived themselves as being especially positioned to improve asylum management.

Another paying patient, Michael C., was more concerned with improving conditions for himself. Prior to becoming a paying patient in Richmond in 1892, Michael had been in the North Dublin Union infirmary ward. While there, he reportedly felt that a nurse had taken 'a dislike to him'. He therefore decided to refuse his food, hoping to be moved to another ward, and was 'very well satisfied with the result of his experiment'. While in Richmond, Michael was described as a:

quarrelsome old man who insists on having his own way in everything. If he has not his own way, he begins to refuse food, knowing well that he will be fed with the tube in hospital. He has taken food from tube for long periods.

Food refusal became an important weapon for Michael. His reasons for doing so varied depending on his latest grievance. On one occasion, he complained that an attendant would not supply him with his full amount of 'stimulants'. On another, he stated that he refused food because he had not been given his morning paper. His ultimate demand, however, was to be allowed to eat his meals in the open air. As illustrated in Fig. 7.1, Michael's wish to eat out of doors was eventually granted and he was photographed having finished one such meal, the crockery lying on the grass beside him in a spacious green area.

Michael was not the only patient who successfully managed to eat meals alone. When Frances N. exhibited 'a curious reluctance to go down to dinner', she was allowed to dine in a separate division. ${ }^{57}$ Nevertheless, paying patients were not generally accorded separate eating quarters from pauper patients. In one instance, a paying patient at Enniscorthy 'attacked a patient ... and flung his tin of tea over him at breakfast' ${ }^{58}$ The victim of this incident was a pauper patient, indicating that the two were dining in the same quarters.

Michael C., used artificial feeding as leverage so often that he became accomplished at feeding himself with the apparatus: ' $[\mathrm{He}]$ has even held the bowl while the tube was passed and has even passed the tube himself'. Later, it was reported that the patient 'will feed himself passing the nasal tube with a certain amount of pride'. The asylum authorities, in this instance, were clearly willing to give into the patient's demands, effectively shifting the balance of power from staff to patient. This 
Fig. 7.1 Photograph of Michael C., male paying patient, Richmond district asylum, 20 May 1900. Appended to 'Male Case Book 18921893', (GM, Richmond District Lunatic Asylum, attached to p. 339)

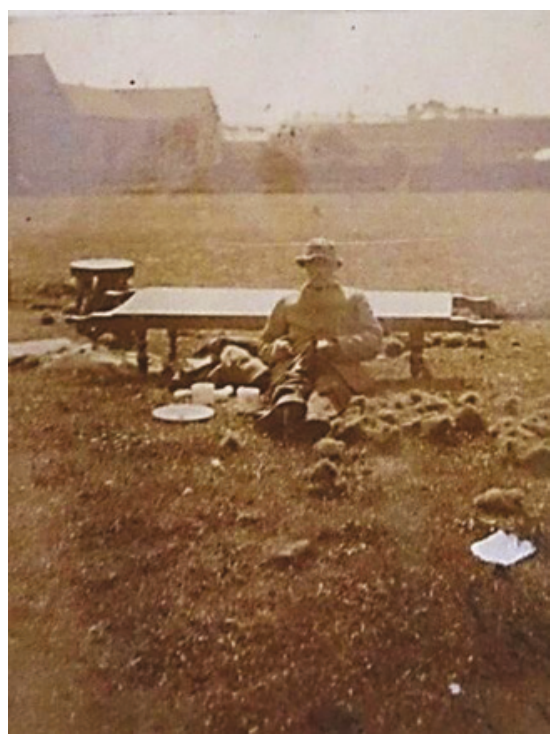

may have stemmed from the fact that Michael was a paying patient. As Andrews has argued, asylum records are often 'prejudiced in favour of the wealthy, educated, articulate or extrovert patient', as these individuals were regarded as more interesting, and received more attention than their less privileged counterparts. ${ }^{59}$ While there is little evidence that paying patients received vastly preferential treatment to pauper patients in the asylums studied, it is conceivable that some were allowed small indulgences. For Michael C., eating outdoors became a regular ritual and it was noted that 'he insists on sitting out in the grounds in all weathers, summer and winter, wet or fine. He says he has no appetite for his meals unless when out in the open air'. ${ }^{60}$ Of course, asylum staff may have preferred this course of action to continually force-feeding the patient.

The main problem with paying patients' diet in district asylums was that it simply had not been designed for this social cohort. Outside the asylum by the post-Famine period, while the staples of Irish diet-potatoes and milk-were beginning to be supplemented with additional foodstuffs including tea, bread, butter, bacon and flesh meat, these changes did not take place in asylums and the lunacy inspectors' main criticism of district asylum dietary was lack of variety. ${ }^{61}$ District asylum dietary was thus now falling below what patients were accustomed 
to eating at home. According to the lunacy inspectors in 1890, at Enniscorthy, the ordinary breakfast consisted of oatmeal, rice in stirabout and milk, tea, sugar and milk, and bread. Ordinary dinner was bread or potatoes, milk and on Sundays, Tuesdays and Thursdays female patients were given one quart of soup. Supper consisted of more bread, tea, sugar and milk and cocoa. Only those on the 'extra' diet were given meat for dinner and the hospital diet was whiskey, wine, eggs, rice, beef tea and any other articles to be 'ordered by the physicians when necessary'. ${ }^{62}$ At Richmond, the ordinary diet was more varied. Breakfast consisted of bread and tea but for dinner, patients were given pea soup or coffee and bread two days a week, beef four days a week and pork on another day. Potatoes were provided twice a week and 'other fresh vegetables' on another three days. For supper, patients were also provided with bread and cocoa, while those on the 'extra' diet received coffee and extra bread at dinner and tea and extra bread at supper. The hospital diet at Richmond was especially varied, including beef tea, chops, eggs, wine, whiskey, brandy, rice, tea, chicken, butter, extra milk, ricemilk, arrowroot and any extras ordered by the physicians. Soup consisting of a 'liquid in which the meat is boiled, seasoned with salt, spices and celery', peas, flour and red herrings was also provided along with cocoa with sugar and milk. Richmond's dietary also provided for Lenten and other fast days for its Roman Catholic patients, consisting of coffee, sugar, milk, bread and butter. ${ }^{63}$ While the dietaries listed in the inspectors' annual reports do not necessarily reveal what patients were given nor the quality of the articles supplied, they do offer an indication of the types of food available to patients.

Voluntary asylum diets were much more diverse. For the period 1820 to 1850, Malcolm has argued that the diet in St Patrick's was 'far more lavish than that offered in district asylums'. ${ }^{64}$ Stewart's asylum had fortyeight acres of farmland and pleasure grounds and this provided 'a large quantity of all seasonable vegetables and potatoes, and the milk of six cows'. ${ }^{65}$ Stewart's medical superintendent, Pim, reported that the dietary in the lunatic asylum branch consisted of bread and butter, tea, coffee or cocoa at breakfast and tea, and soup, fish, meats in variety, potatoes and an 'abundance of vegetables all of the best quality' for dinner, with an after-course almost daily. Alcoholic beverages were not allowed unless specially ordered by a medical attendant. ${ }^{66}$ This contrasted with Bloomfield, where beer and wine were not listed under medical expenditure, suggesting that alcohol formed part of the dietary there. ${ }^{67}$ Both the 
lunacy inspectors and patients appeared to approve of the diet on offer at Stewarts. After visiting the asylum during dinner in 1871, Hatchell reported that 'the food was of excellent quality, and the allowance to each was liberal'. ${ }^{68}$

The diet at Stewarts included a large amount of fresh produce; a garden of three statute acres reportedly 'daily supplies the house with an abundance of every ordinary vegetable in season, and during the fruit months such delicacies as gooseberries, currants, apples, pears, \&c., are liberally distributed'. In addition, the asylum farm provided 'all the necessaries for such an establishment (excepting meat, bread and butter)'. Surplus produce from the farm was sold in the Dublin markets, suggesting that it was producing more than enough for the patients. ${ }^{69}$ Similarly, at Bloomfield in the 1850s, the gardens and grounds were 'rendered highly productive by judicious cultivation'. ${ }^{70}$ As has been shown, several male patients worked in the vegetable garden, suggesting that Bloomfield possessed a degree of self-sufficiency. Stanley was clearly protective of the vegetable garden. On one occasion, he had patient William R. confined for a few hours in the padded-room 'to prevent him plucking up the vegetables or injuring anyone by throwing stones across the walls' ${ }^{71}$ In 1864, Stanley recorded the purchase of two pigs from Smithfield Market, suggesting that patients were also provided with pork. $^{72}$

While glowing committee reports concerning the diet at Stewarts should be regarded with caution, given that they were intended to bolster the institution's reputation, it is noteworthy that there were no food-related criticisms recorded in the case notes. In contrast, patients at Bloomfield did complain about their dietary. Isabella K., exhibited 'some difficulty about her food' and would eat only stirabout, milk, beef tea and bread, and later on an egg and tea. Isabella refused to speak other than to request food, suggesting that diet was an important element of her life at Bloomfield. When she eventually spoke to the reporting physician, he asked her to take some meat, but she replied, 'I was just going to ask you not to give me any more food ... I don't want to get well. ${ }^{73}$ Another patient, John Francis H. was 'very hard to please about his food', despite reportedly taking an 'abundance of food, such as he wishes for, e.g. bread, butter, fruit'. Like Isabella, John Francis also refused meat and eventually insisted on subsisting only on bread and water. ${ }^{74}$ While voluntary asylum patients clearly had more say over what they ate compared with paying patients in district asylums, when 
they refused food, artificial feeding was resorted to. ${ }^{75}$ When Bloomfield patient John F. 'persisted in living on bread and water' and 'seemed to suffer in health', he was artificially fed with liquids, beef tea, milk and eggs' and subsequently had 'eaten and drunk freely'. ${ }^{76}$

Private asylum patients also expressed anxieties about their food. St John of God's patient, Edward A.P., said to have 'a great appetite is the first and the last out of the refectory', was:

never done grumbling that he does not get enough of meat - beef steak which he thinks he should receive three times daily ... The coffee is 'dirty water not fit for a dog'. The food 'is not what I am accustomed to: it is not fit for a priest'.

Not unlike the district asylum doctors, O'Connell interpreted these complaints as indicating the patient's greed, stating, 'I believe he would eat meat ten times a day if he got it. He complains because he does not get it for supper in addition to getting it at breakfast and dinner."77 Christopher C., a barrister, was also reportedly particular about his food:

Very closely inspects any bit of food he likes, but it is not possible to please him ... If, for example, he be given fried eggs at breakfast, he says he prefers boiled eggs. If the eggs be boiled, then he wants them fried. ${ }^{78}$

In this instance, O'Connell attributed Christopher's behaviour to his fear 'to eat lest he or his friends cannot pay for his support. Always gives as an excuse for not eating heartily, that the food disturbs him'.79

These complaints in the more expensive asylums, Bloomfield and St John of God's, suggest that diet was a subjective and important element of patients' expectations. Nonetheless, it is likely that voluntary and private asylum patients were supplied with meals that more closely resembled what they had eaten at home. Paying patients in district asylums were thus at a disadvantage, as the medical principle of supplying patients with their accustomed dietary or better was eclipsed by the legal requirement to limit them to the pauper patient's dietary. 


\section{Class, Religious and Political Tensions}

As we have seen, during the 1857-1858 commission of inquiry, the lunacy inspectors and numerous asylum doctors were worried about the intermingling of patients from various social classes, fearing jealousies would arise between them. In practice, accommodating paying patients in district asylums did create tensions, not just between patients, but with attendants and medical staff. This mostly stemmed from paying patients who disliked mixing with those from a different social background. ${ }^{80}$

Case notes reveal that some paying patients at Enniscorthy tended to associate with one another, perhaps forming their own sub-group within the asylum population. Many paying patients walked together. James C. walked in the grounds with James S. every day, while Bridget $\mathrm{C}$, a nun, and Johanna F., a farmer, also kept company in the grounds. ${ }^{81}$ Other paying patients disliked mixing with others. As Richmond paying patient, Elizabeth H., stated:

I hate being here with these dirty abominable women - their dirty language at meal-times ... Says she does not like to sit at the fire, owing to the disagreeableness of the other patients. The nurses might prevent the annoyance the pts give if they like, but they don't. ${ }^{82}$

Several paying patients apparently looked down on other patients and servants in the asylum. For example, James S., a farmer who had previous been in St Patrick's voluntary asylum, paid $£ 25$ per annum at Enniscorthy. While in the asylum, he complained: 'this is no place to have me, they are all madmen and ruffians here. ${ }^{83}$ Frances N. in Richmond was eager to differentiate herself from pauper patients: 'said she was not a pauper like the others although she was wet and dirty'. 84

Class tensions between paying patients and asylum staff also came into play. In the Morningside asylum in Scotland, many of the more affluent patients looked down on the attendants and found it undignified to take orders from those they considered their 'coarse and uncivilised' social inferiors. ${ }^{85}$ Asylum staff in Ireland tended to be drawn from the less affluent, while the demanding nature of the job caused a high turnover in staff. ${ }^{86}$ District asylum staff were regularly drawn from the military, because of their experience of working in disciplined roles, ${ }^{87}$ although 
it is unclear whether voluntary and private asylums attracted similar attendants.

Female paying patients at Richmond were particularly vocal about their distaste for asylum attendants and physicians, possibly stemming from the large number and high turnover in this institution. Rose C. 'wrote a letter full of abuse of the doctor, attendants, patients and the asylum generally' ${ }^{88}$ Rebecca B. considered 'Dr. Norman the greatest scoundrel on earth', while Catherine B. was described as:

extremely disdainful in manner. Says an heiresses' life would suit her ... objects to associating with Nurse Murphy and Nurse Hagans and doctors and shadows. Says she should own this institution ... Says I am taking a great liberty in speaking to her. ${ }^{89}$

Mary Jane A. was clearly unhappy with her life at Richmond:

'Oh to think I'm here' 'Oh what sort of a place is this' 'Oh what is going to be done to me at all - to think that I was born to die in some wild place like this - oh what will happen when you are all away and nobody near me - oh what will I do. What is to become of me at all?' She is too agitated for any coherent conversation. She says 'to be walking about among a lot of dead people, not near a shop or anything - is not it terrible?'90

On the other hand, some paying patients were apparently pleased with their accommodation and attendants. Maria F. spoke most highly ' ... of this Asylum, saying we are "blessed with good attendants" and expressing the highest recommendation of our arrangements'. ${ }^{91}$

At Enniscorthy, James C. had a blatant distaste for servants and asylum staff. Prior to his admission, James attacked a servant in his brother's house, threatening and striking him. ${ }^{92}$ He told Drapes that:

his brother's house is being robbed by a servant man named Dillon, that they have stripped the house of glass and delph, also that another servant named Margaret is in on the robbery. He adds that another man named Ennis who was in his brother's employment was a damn ruffian and that he assaulted him on one occasion, giving a box in the head.

Drapes considered this tale to be 'all a delusion'. While in the asylum, James' aversion towards attendants and servants continued. He threw stones at a painter and a few days later attacked one of the attendants in 
the same manner, insisting both men had threatened him. ${ }^{93}$ Eliza M. also reportedly slapped the male servants. ${ }^{94}$ While district asylums were often witness to outbreaks of violence between patients, nurses and attendants, ${ }^{95}$ existing tensions in the relationship between staff and patient could only have been exacerbated by social inequalities between the two parties. This is further evidenced in a note on Hampstead patient, Richard Charles Edward M., an army lieutenant:

Last night he had been unusually noisy, restless \& excited up to $2 \mathrm{am}$. About an hour \& a half after this he suddenly became rational, asked why the atts were holding him in bed, said his father's servants wd not be permitted to do so, that he was a gentleman \& shd be treated as such. ${ }^{96}$

At St John of God's, staff struggled to manage patient James Edward G., a medical student:

He remains in bed in the morning much longer than was his habit a year or two ago, and, in consequence, does not come to breakfast often till all others are finished. The attendants are afraid to make him get up earlier. ${ }^{97}$

According to O'Connell, former grocer, John B., also gave his attendants trouble: 'he frequently defecates in his trousers to annoy the attendant ... frequently dirties his clothes, sometimes wilfully to give annoyance'. ${ }^{98}$ Patients' hygiene was also a subject of remark by O'Connell and some patients could not be induced to wash themselves. Of one patient, a lay brother, he reported, 'he never takes a bath-occasionally washes his feet ... Three weeks ago, he was compelled to take a bath the first I ever knew him to take'. ${ }^{99}$ In 1903, another patient, a clerk and bookkeeper, was described as:

Dirty, filthy, most inquisitive, abusive and [?] as usual. A troublesome, dangerous man. I wish he were out of this Asylum ... dirty and he never bathes - I have never known him take a bath. He says he took only one while in the House!! 100

O'Connell's distaste reveals the tensions between private asylum staff and their wealthy clientele. Yet, disputes could work in favour of patients. In Hampstead in the 1840s, when a servant woman allegedly provided a patient, Helen H., 'with a key to make her escape ... the servant was discharged on her accusation \& on the servants own confession'. ${ }^{101}$ Half a 
century later, Hampstead patient, George G., was visited by the Registrar in Lunacy to whom he complained of the 'roughness of Att. Craber'. In response, John Neilson Eustace 'gave Att. C a month's notice on the following day as I had previously cautioned him'. ${ }^{102}$ This suggests that private asylum patients, by virtue of their high social standing, exercised greater influence over their conditions of care.

In voluntary asylums, paying patients were usually kept separate from free patients and, accordingly, class tensions between patients arose far less frequently. In addition to classification by sex and severity of illness, moral management stressed the importance of segregating patients by social class. ${ }^{103}$ Although Bloomfield did not strictly follow this principle, additional privacy was accorded to those maintained at the highest sums. Nonetheless, some patients disliked mixing with others. A Bloomfield patient, Anna C., would 'not on any account mix with the other ladies' and as a result, the reporting physician had 'great difficulty in getting her open air exercise'. ${ }^{104}$ Similarly, at Stewarts, patient Eli S., a dental mechanic, objected 'to having to associate with other patients says he is a gent and they are pigs, not society for him'. ${ }^{105}$ Another patient, Adelaide Amy J., appeared to Rainsford:

to think that she is a person of great importance and much too good to associate with anyone about the place ... She refuses as a rule to look at anyone and hides her face with her hand when speaking and suddenly runs away to some more quiet place ... Refuses to come near me and runs away when I approach her ... Says I have nothing to do with her that she has to consider her father's name. ${ }^{106}$

Although she was later reported 'to talk to the other patients and seems rather pleasanter and in better spirits', she subsequently 'threw a cup of tea over a gentleman who was in the dining room saying that he was robbing her of her tea'. Two months later, Adelaide developed a notion that she was in danger of becoming diseased and wrote 'to her mother demanding her removal owing to contagion'. Unfortunately, Adelaide's attempt to interact with other patients was frustrated when another patient, Mrs. B., 'ran after her when out walking with a nettle. Miss. J. much upset. Took to bed and said she had typhoid'. Following this, she declined to speak to Rainsford or any of the patients and refused to go out walking with them. She later complained that 'all around her are dressmakers \&c not fit for her to associate with'. ${ }^{107}$ 
Alongside social class, religion played an integral role in patient identity. In spite of the political and religious tensions in society at large during the period studied, this was not seen to impact to any great extent on the mental health of patients in the study. Nonetheless, there is evidence of class and religious tensions between patients and sometimes staff. It is difficult to disentangle religion from class identity in this era. By the mid-nineteenth century in England, religious denomination gave a distinctive identity to particular communities and classes, the most notable being the association between the middle class and a Christian way of life. ${ }^{108}$ Adherence to evangelical Protestant forms became an accepted part of respectability, which increasingly came to include church-going, family worship and an interest in religious literature. ${ }^{109}$ In post-Famine Ireland, attitudes shifted towards a range of social and cultural behaviours, including a dramatic alteration in devotional routine that culminated in a more respectable, mid-Victorian Irish populace. ${ }^{110}$

In addition to links between religious observances and respectability, in Ireland, religion could be a marker of one's political affiliation. Both religious and political tensions ran deep in Irish society and these could permeate asylum life. Although psychiatry held mixed views about the effects of religion on mental health, religion was believed to have a potentially positive influence on the mind and the provision of religious services formed part of the therapeutic regimes in Irish asylums. Nonetheless, the provision of religious facilities intersected with anxieties about the vulnerability of institutional inmates to proselytising. ${ }^{111}$ Frictions arose between asylum staff and local clergymen during the 1840s about the degree of access Catholic parish priests were accorded to the Carlow asylum, as there were fears it would become a 'domain of Protestant influence'. 112 There were also heated debates surrounding the appointment of chaplains in the Belfast asylum, which admitted members of seven different creeds during the 1850s and 1860s. ${ }^{113} \mathrm{By}$ the mid-nineteenth century, however, most medical superintendents in Britain and Ireland 'were happy to have official chaplains fulfil the role originally carried out by the lay moral manager' and in 1867, the Lord Lieutenant of Ireland was empowered to appoint chaplains to district asylums. ${ }^{114}$ Religious tensions in district asylums continued into the twentieth century. At Ballinasloe asylum, the asylum board prohibited the establishment of a Catholic chapel within the asylum grounds, fearing a 'Catholic takeover of the institution itself' and signifying broader 
political concerns at a time when schools, hospitals and universities were denominational. ${ }^{115}$

As we have seen, paying patients in district asylums tended to be disproportionately Protestant compared with both pauper patient populations and society at large. This resulted in an increased intermingling of patients from different religious persuasions which bred religious and political tensions in the asylums. In 1901, an Enniscorthy paying patient, Edward S., was said to have an 'aversion to Protestants, all of whom he regards as Orangemen. Moore [an attendant] often hears him muttering when he passes, e.g. that if he had the chance he would do away with all "Orangemen", and Protestants'. Edward also accused a fellow Roman Catholic inmate of becoming a Protestant to 'get the privileges', which Drapes interpreted as 'being allowed to walk about on parole'. Edward's distaste towards Protestants extended beyond those in the patient population. Drapes, an active member of the Church of Ireland, also came under fire: "told me more than once that it was my "bigotry" which was keeping me here: and that it was I who got him sent here'. ${ }^{116}$

The extent to which religion was essential to patient identity is further indicated in the case of another Catholic paying patient at Enniscorthy, Lawrence D. In 1896, as part of a rather extensive campaign to avenge his wife, brother-in-law and former solicitor, whom he charged with wrongful confinement and forgery, Lawrence wrote to his parish priest, David Bolger. The letter is worth quoting from at length, as it is exemplary of religious preoccupations among not only paying patients, both also the Catholic clergy in Wexford:

I will thank you to send me here a post office order for one pound, the amount I gave for a Baptismal Fee at the Baptism of my infant son Lawrence John: I had then more money than brains, and I have now more brains than money ... You did not think it worth your while or trouble to answer my letter of the $21^{\text {st }}$ June, although you could lecture me in the jail of Wexford on the $30^{\text {th }}$ July 1895 and tell me that it was a shame for me to employ a Protestant solicitor ... I replied that the last solicitor I employed was not even a Christian, he is a Jew ... I know now how a Catholic solicitor served me and he is now in the hands of the police ... I will tell you how a Protestant Nobleman, Lord Maurice Fitzgerald treated me. I wrote to him on the $23^{\text {rd }}$ ult. and had his reply written from Johnstown Castle on the $27^{\text {th }}$ July at one o'clock on the $28^{\text {th }}$. So much for the Protestant son of Ireland's only Duke ... So much for Catholics, Protestants and Jews 
... Mind don't forget sending the money as I require it for my solicitor. Lawrence D. ${ }^{117}$

The patient's disillusionment with the Catholic Church is evident in his demand for the return of the $£ 1$ baptismal fee, which he now judged as an ill-conceived gesture. Lawrence's disenchantment with Catholicism appears further heightened by his admission that his former Catholic solicitor is now in prison. The priest's alleged distaste for a Protestant solicitor further indicates that religion played an important role in identity in late-nineteenth century Wexford outside the asylum as much as inside.

Religious tensions were also perceptible in the Richmond asylum. For example, Ellen C., a Protestant woman who had been previously confined in Stewarts:

Would forgive her husband anything, but putting her where the majority are Roman Catholics. Considers that her kneeling to say her prayers is made a subject of remarks. On my pointing out to her that many patients are seen kneeling in the dormitories, she replies, 'They are Roman Catholics'. Complains that Mary M talks to her about priests and nuns. ${ }^{118}$

Catholic paying patient Edward F. reportedly felt that he was being kept from attending mass:

during the isolation due to Beri-beri, he suffered much annoyance by being kept from attending his church. However, he laid the whole moral responsibility off his own shoulders and on Dr. Norman's. ${ }^{119}$

Ellen O'C., a Catholic paying patient aged seventy-four, seemingly resisted examination on religious grounds: 'When I went to examine her she got over excited and said it was wrong and immodest of me to go near her. She kept constantly praying and asking "are you all Catholics"'.120

Relatively little evidence exists of religious tensions between the wealthier clientele in voluntary and private asylums. This is despite the mixing of patients from various creeds (see Chap. 4). One reason for this stemmed from the religious characters of these institutions. In the 1860s, Bloomfield provided religious services for Quaker patients. ${ }^{121}$ However, when queried on what provision existed for the religious attendance of those of other denominations during the 1857-1858 commission, Bloomfield's superintendent, John Moss, asserted 'we are 
not visited by any ministers of other denominations, unless a patient requires it, or his friends'. This was arranged on admission and Moss claimed that 'we have not the least objection to the ministers of their respective religious denominations visiting them'. ${ }^{122}$ By the 1890s, an Episcopalian clergyman also visited the house every fortnight, but no patient was considered capable of attending Divine service outside the asylum. ${ }^{123}$ Divine services were held weekly in Stewarts for Protestant and Catholic patients and the RMS reported that attendance to both was 'very considerable'. In addition, those who were 'capable' were permitted to attend their places of worship on Sundays. ${ }^{124}$ The lunacy inspector, E.M. Courtenay, praised Stewarts for providing religious services, stating that 'the religious wants of the patients appeared to be carefully attended to'. ${ }^{125}$ Certainly, although Jane M., a Church of Ireland patient, became 'very excited' one afternoon when she was not allowed to attend a service, it was later noted that she was able to go to church on Sundays. ${ }^{126}$ Meanwhile, Maude Frances C., a Catholic, attended mass at Chapelizod. ${ }^{127}$

The lack of religious tensions between voluntary and private asylum patients suggests the asylum authorities proactively avoided potential difficulties arising from accommodating patients of various creeds. This is reflected in Stanley's record of preparations to receive Lady R., the daughter of a Baron and a member of the Church of Ireland, in Bloomfield in 1868:

Doctor Owen made a visit of inquiry today respecting the admission of
a daughter of Baron R[-] who is insane on Religious matters - the lady
it appears has a great dislike to Roman Catholics and although a special
attendant is not required, she should have a Protestant Servant to attend
her ... It was the intention of her Friends to have her placed in a private
Family, but the Baron who came here last week with Doctor Owen on a
visit of inspection liked the place and the Doctor wishes to be informed
the terms with and without an Attendant and if such a Servant would be
provided. ${ }^{128}$

The appropriation of staff of the same religion was not unusual in nineteenth-century Ireland. Church of Ireland families, in particular, tended to hire servants of their own faith. ${ }^{129}$ Although there is no record of Lady R. being admitted to Bloomfield, her case reveals that those providing care for the wealthier classes were mindful to achieve a balance 
between supplying religious services for those who wanted them and negating against any religious divisions that might arise in institutions receiving patients of various, often conflicting, religious persuasions.

Inextricably linked with religious tensions and class identity in Ireland was political unrest. In her study of the Ballinasloe district asylum, Walsh has found patients discussing the various bodies of political opinion and the same can be said for paying patients in the district asylums studied here. ${ }^{130}$ In his 1894 article on the alleged increase of insanity in Ireland, Drapes argued:

the almost constant political agitation to which our people are subjected, deeply arousing, as it does, the feelings of a naturally emotional race ... Mr. Lecky says somewhere, 'Religion is the one romance of the poor.' There is another which, as a vision of the future haunts the mind of the Irish peasant. Rent abolished, his land and homestead for himself, and a Parliament in College Green, these make up the dream which fills his fancy. Disappointed often, but still not despairing, betrayed as he has often been, he still clings with a wonderful tenacity to the picture of an ideal Ireland which his imagination, aided by the eloquence of his political teachers, has fabricated. But the hopes, fears, and anxieties, the stirring up of emotions, some evil, some generous, engendered by this almost chronic condition of political unrest, can hardly fail to have a more or less injurious effect on a not over-stable kind of brain, and such as those who, like Gallio, care for none of these things, may find it a little difficult to realise. ${ }^{131}$

These assertions betray Drapes' own political and class stance and his wishes to maintain existing class and political structures. ${ }^{132}$ Although Drapes focused on the 'Irish peasant', these events held equally distressing ramifications for wealthier groups and discussion of political unrest was prevalent among Richmond's paying patients. Among Catholics, Anne R. had visions of St Patrick and Daniel O'Connell and heard Charles Stewart 'Parnell's voice every day calling her bad names'. ${ }^{133}$ John C., a soldier pensioner 'talks in a silly rambling incoherent manner about Mrs. O'Shea, priests, Parnell, bloody Fenians \&c'. ${ }^{134}$ Protestant patients were equally preoccupied with political figures. Mary A F stated 'I am Queen Victoria' and later 'I am Robert Peel's wife'. ${ }^{135}$ Hannah Louisa F talked 'incoherently about Mrs. O'Shea', while Fanny M. referred to "Mr. Gladstone as a "beast". ${ }^{136}$ Prior to her confinement in Richmond, Mary B. had been in the Armagh Retreat private asylum. 
Mary, whose mother described her as being 'of a philanthropic turn' and a 'trustee for some money for 20 poor ladies' had complained on admission, 'says the government are not giving her good value for her money and talks of leading a rebellion against the Government'. ${ }^{137}$ After just one day at Richmond, Mary was discharged to a private asylum.

There is no record of voluntary or private asylum patients discussing politics with their doctors. Nonetheless, in her study of St Patrick's voluntary asylum, Malcolm has strongly argued that events like the 1916 rising and the civil war often had a 'significant impact on the mental health of Irish people', not just on soldiers engaged in military service, but on civilians. ${ }^{138}$ She also cites William Saunders Hallaran's identification of the 'terror' caused by the 1798 rebellion and finds supporting evidence in the patient records for St Patrick's. ${ }^{139}$ In this sample, there was only one reference to political upheaval. When Mary Julia G.C., was admitted to Bloomfield in the 1860s, she was reportedly 'very terrified of Fenian Mischief'. ${ }^{140}$ In the admissions register, the cause of her mental illness was attributed to her 'living a solitary life. Bad management of her own state of health and brought to a crisis by panic from imaginary Fenians at Wicklow'. Unfortunately, there are no surviving case notes on Mary Julia, so it is not possible to learn whether she continued to speak of her political anxieties following admission. Mary's fear of 'Fenian Mischief' does, however, inform of her political views. The relative prominence of issues surrounding class, religion and politics in the case notes on district asylum paying patients says much about contemporary medical perceptions of non-pauper mental illness. Reporting physicians clearly felt it worthwhile to record patients' anxieties about their political and social status and in turn their class identity. Yet while there is evidence of class and religious tensions between patients and staff, in most cases voluntary and private asylum authorities managed to avoid these by segregation and provision of religious ministrations for all denominations.

\section{Expectations of Patients}

Historians of Irish asylums have highlighted the high levels of violence perpetrated by patients and their carers. ${ }^{141}$ Violence became key to lay cultural understandings of insanity to the extent that asylums became intrinsically linked with 'dangerous insanity'. ${ }^{142}$ Interpretations of the dangerous lunatic legislation are at the centre of these discussions, 
as it framed an important route of admission into district asylums. ${ }^{143}$ Individuals considered as dangerous and of unsound mind could, following 1867, be committed directly to district asylums, effectively bypassing more tedious, bureaucratic and often unsuccessful routes into the asylum. ${ }^{144}$ Importantly, the 1867 Act pertained only to district asylums; it did not provide for dangerous lunatics being committed to private or voluntary institutions. Yet, there is little doubt that a number of the patients received there exhibited violent and even dangerous behaviour.

By the 1890s, asylum case notes contained a field marked 'dangerous to others'. Table 7.1 reveals that those committed to more expensive asylums, particularly Hampstead and Highfield, were the most frequently described as being dangerous to others. The diagnoses assigned to patients in this study also reveal medical recognition of violent symptoms among paying patients. The two primary diagnostic categories of mania and melancholia encompassed a wide range of symptoms and behaviours. ${ }^{145}$ Of the two, mania, which was medically associated with violence and disruptiveness, was the more common diagnosis, accounting for almost half of first admissions (see Table 7.2). Melancholics were the next largest group, constituting over one-fifth of first admissions. Aside from these two classic diagnoses, a much smaller proportion of paying patients were diagnosed with dementia, general paralysis, epilepsy or other far less common conditions such as paranoia, imbecility and congenital mental deficiency. Paying patients in rural asylums, Ennis (65.8\%) and Enniscorthy $(73.1 \%)$, were particularly prone to mania diagnoses. This contrasts with the neighbouring Carlow asylum, where only 39\% of diagnosed patients (pauper and paying) were identified as suffering from mania, ${ }^{146}$ and implies that paying patients were perceived as being especially violent. Male (46.4\%) and female (46.5\%) paying patients had almost equal chances of being diagnosed with mania, suggesting that women were considered just as capable of violent acts as their male counterparts. Certainly, violence was a distinctive feature of asylum life and perpetrated by paying patients of both sexes. The disruptive behaviour which characterised mania posed challenges to the moral therapy regimes. ${ }^{147}$

Voluntary and private asylum patients were reportedly particularly violent. At Bloomfield, patient John P.I. was 'liable to outbursts of violence and has assaulted patients and attendants but less so latterly'. ${ }^{148}$ Another patient, Mary L., 'pulled Maria's [the attendant's] hair and kicked her'. ${ }^{149}$ Violent behaviour also extended to elderly patients. Thomas 
Table 7.1 Proportion of patients described as 'Dangerous to Others' in case notes on Bloomfield, Stewarts, St John of God's, Hampstead and Highfield patients, c. 1890s

\begin{tabular}{lllll}
\hline & Yes & Yes (\%) & No & No (\%) \\
\hline Stewarts & 4 & 10.3 & 35 & 89.7 \\
Bloomfield & 9 & 16.1 & 47 & 83.9 \\
St John of God's & 17 & 22.4 & 59 & 77.6 \\
Hampstead & 14 & 50.0 & 14 & 50.0 \\
Highfield & 4 & 66.7 & 2 & 33.3 \\
\hline
\end{tabular}

Compiled from Bloomfield, Stewarts, St John of God's, Hampstead and Highfield casebooks

J.G., a seventy-eight-year-old retired bookkeeper, was believed to have attacked his wife and in consequence was sent to Bloomfield. While there, he struck another patient 'with a stick, cutting his head'. Although there was no record of him being punished or restrained for his actions, it was noted that 'since then we have not given him any stick'. Thomas was clearly of a violent temperament. He later became 'vexed because his room was being cleaned and struck the attendants and cursed violently'. ${ }^{150}$

Patients of all ages, both male and female, regularly attacked attendants and other patients. ${ }^{151}$ Patient injuries included bruising, flesh wounds, scalp wounds and suspected fractures. Black eyes were particularly prominent among patients sent to Stewart's during the 1890s. ${ }^{152}$ This is in stark contrast to a statement from the managing committee in 1894, which insisted:

As far as possible, the admission of patients likely to be unsuitable and cause inconvenience to other patients is discouraged, and if any, after admission, are found objectionable, due notification is given to their friends in order that other arrangements may be made. ${ }^{153}$

Despite their reassurances, the managing committee did not discharge patients who were violent or disruptive and many 'harmless' patients were subjected to abuse. ${ }^{154}$ Private asylum patients could also be violent. Highfield patient, Christina McF S., reportedly screamed, cursed and sometimes attacked the attendants. ${ }^{155}$ At St John of God's, Joseph B. one night 'got up and beat a fellow patient sleeping in the same 


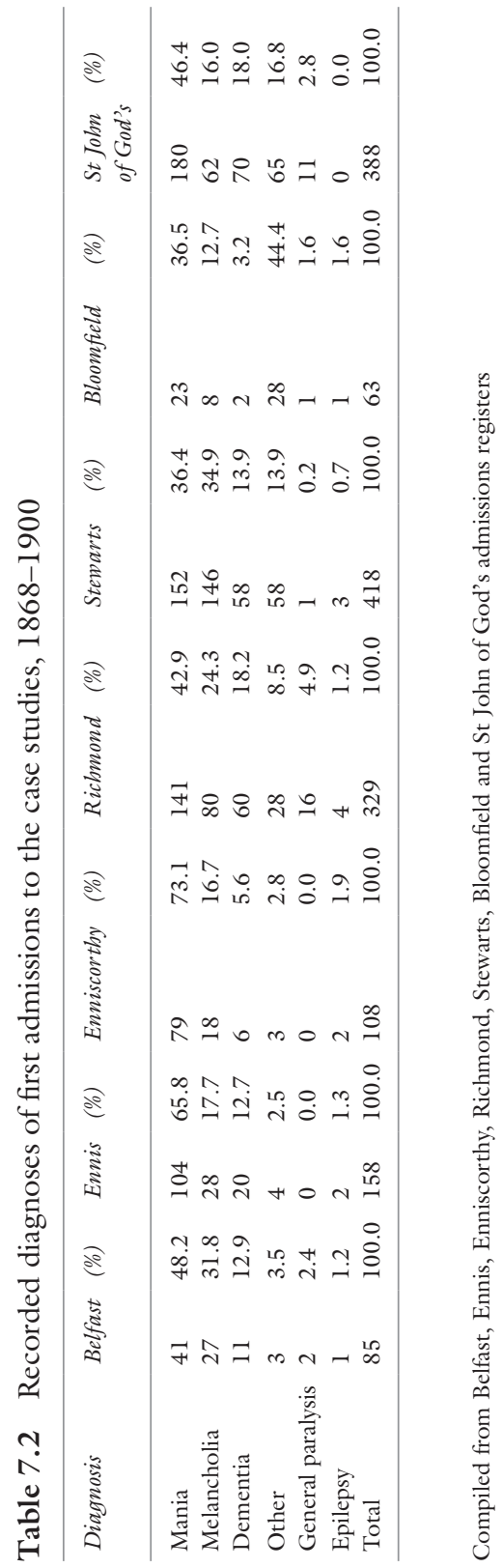


dormitory with him. When I asked why he did it, he said so and so was laughing at him. Since then he sleeps in a locked room off the dormitory'. ${ }^{156}$ Although this was apparently an isolated incident, other patients had a track record of violence. Patrick F., a medical student:

suddenly and without any provocation, came up behind Father P who was kneeling, pulled back his head and gave him a blow in the right eye. On August 8 in chapel, he got up and went over where Dr C was kneeling and struck him. Both acts were impulsive ... he had a fight with Father P and received a few blows on the right cheek [?] of the nose.

O'Connell noted, 'I am not sure that he was the aggressor. At any rate this is the second time within a year he struck Father P. against whom he seems to entertain a grudge'. ${ }^{157}$

Injuries were usually attributed to the violence of another patient. However, in some instances patients received injuries from attendants and doctors. The case of Frederick Healy W., a judge's son, reveals the extent to which violence had permeated the atmosphere at Stewarts in the 1890s. Frederick, who was very 'bad tempered' and had previously struck a fellow patient 'on [the] forehead with a poker', began to complain of a pain in his side where he said 'he was kicked by [another] patient'. Rainsford later noted that Frederick was 'very quarrelsome. Has both eyes blknd [sic] one by Dr. Hunt in a quarrel, the other by falling off a chair when quarrelling with the carpenter'. ${ }^{158}$ Henrietta C.K., a 'lady', also received a black eye 'from struggling when being forcibly fed', while Margaret Anne C. 'got a push from a ward maid whilst interfering with bedmaking and falling cut her forehead against a rail'. ${ }^{159}$ Although violence and bodily harm among patients and staff in public asylums is well documented, this high level of injury among voluntary asylum patients reveals that the often large sums of money paid to institutions such as Bloomfield and Stewarts did not guarantee patients' protection.

Importantly, tensions between patients and staff in voluntary asylums may have been amplified in the casebooks because asylum interactions were recorded selectively. While asylum doctors were compelled to account for patient injuries and violent incidents, they were not obliged to record amicable staff-patient interactions. ${ }^{160}$ In this study, the degree to which staff mixed with patients is difficult to assess, given the relative absence of documentary evidence. Bloomfield's 'Notice of Particulars', 
kept by house stewards Hyde and later Stanley in the 1860s, is thus instructive in its more nuanced rendering of asylum life. It suggests that, at least in small asylums like Bloomfield, where low patient numbers still facilitated moral therapy, patients and staff could enjoy one another's company. Stanley, who ran errands on behalf of Bloomfield almost daily, often brought one or more patients along with him for the outing. Early on in his career as house steward, he apparently became attached to one patient, a William R.:

Mr R[-] being so very steady today Mrs Pryor kindly gave me permission to bring him with me to Dublin where I had some business to transact. Being anxious to try the power of his memory, I asked him in the Roy. Bank ... the day of the month and he replied immediately the $28^{\text {th }}$ without taking a moment's consideration. We then went to the North Wall to ascertain if the Steam Boats were plying to Kingstown as he is anxious to have a trip there, either by rail or boat ... It is, I believe, Mrs Pryor's intention to send him there as soon as it shall be found convenient. ${ }^{161}$

Stanley continued to bring William with him on errands for a number of days, on one occasion even buying him 'a pair of gloves which he wanted very badly'. ${ }^{162}$ Sadly, when William relapsed a few days later, Stanley, who had commenced his position as house steward just two months earlier, was clearly unprepared:

My poor friend Mr. R[-] I am sorry to say took a change last night although when I was leaving Bloomfield yesterday for home appeared to me to be as steady as he has been all the week ... One can scarcely imagine him to be the same person who accompanied me so often to Town and who reminded me of the different places to which we had to call. Here he is today crying and laughing at intervals - One time walking along the corridor as fast as he can, and another time tumbling head-over-heels from one side of it to the other. He will then come into the sitting room - take down the Testament, and read aloud five or six verses, crying and laughing over them alternately. Such is the state he would be seen in today after a week of steadiness spent in a way which he enjoyed so very much. ${ }^{163}$

Stanley's experience with William evidently did not deter him from socialising with the other patients. During his time as house steward, Stanley introduced 'football recreation' and actively joined in. $\mathrm{He}$ also played musical instruments for the patients in the evening, and he and 
his wife (who was the head attendant on the female side of Bloomfield) often brought groups of patients on trips together. While this portrayal of Stanley's relationship with his patients is rather positive, it offers an important counterpoint to the usual records of violence and tensions between patients and asylum staff.

The management techniques for violent patients in voluntary asylums were often similar to district asylums. However, patients maintained at high fees or whose relatives could afford to pay extra were sometimes given a personal attendant in place of the more usual method of restraint. By the late nineteenth century, the employment of special attendants for St Patrick's patients was less common and straitjackets became the preferred means of control. ${ }^{164}$ Although Bloomfield remained a small institution and Stewarts was sometimes underfilled, several patients there were subject to restraint, seclusion or sedation, implying that these asylums had fewer disposable funds to supply special attendants. For example, in 1893, when Mary Elizabeth A. attacked a female attendant and tore her bedclothes, a 'restraining jacket' was applied for two hours and she was later given sulphonal. When the same patient attempted to 'throw herself downstairs' she was again restrained. Following another incident, the doctor noted that the jacket 'always quiets her and seems to do her good'. She later began to break windows in the asylum for which she was restrained and then given potassium bromide and cannabis. It is clear the straitjacket was being applied in a punitive manner. On one occasion, the reporting physician noted that 'the screaming was so bad that to try and stop it the straitjacket was put on about a month ago for a few hours at a time by way of punishment'. ${ }^{165}$

In keeping with moral therapy's emphasis on maintaining harmonious surroundings, staff in voluntary asylums seemed vigilant in their attempts to protect 'harmless' patients from those posing a threat to social order. Accordingly, reporting physicians judged patients' behaviour against that considered appropriate for the wealthier classes, frequently noting, for example, if a patient looked 'ladylike'. ${ }^{166}$ Both the doctors and relatives of voluntary asylum patients assessed appropriate forms of female behaviour. ${ }^{167}$ This included appraisal of their actions, language, clothing and appearance. Any form of embarrassing behaviour or deviation from social norms was considered evidence of mental illness. Thus, when Caroline J., a forty-seven-year-old governess was admitted to Stewarts in 1900, the asylum doctor reported that she had 'all her life strange views of men imagining they were in love with her and lately has imagined attempts 
were made to rob her of her virtue. Was inclined to be fond of alcohol and drank stout'. To his evident surprise, on admission she was 'quiet and ladylike. Took her meals and gave no trouble'. ${ }^{168}$ The extent to which one was 'ladylike' was apparently a measure of sanity for female patients at Stewarts. When Charlotte Maria D. began to recover, it was noted that she was 'mentally much improved. Very quiet and ladylike'. ${ }^{69}$

Asylum doctors at both Stewarts and Bloomfield disapproved of patients using bad language or other 'indecorous behaviour' and frequently recorded incidents where the social decorum of the asylum had been breached. ${ }^{170}$ In 1896, Charles Henry B. had reportedly been 'speaking so constantly ... to the gentlemen in the billiard room' at Bloomfield, that it was found 'necessary to keep him in his room upstairs'. ${ }^{171}$ Charles Henry allegedly spoke in a most objectionable way' when the physician entered his room and accused the attendants of 'gross immorality'. The doctor, fearing other patients would hear him, placed Charles in solitary confinement:

Every five days he goes out for two hours. I much regret his confinement in his room but I cannot see how it is to be avoided. He would greatly injure the other gentlemen if he talked to them in this manner. ${ }^{172}$

Likewise, at Hampstead, William Henry D. was removed from the main dining room to the 'second where the No l patients are' because:

he continually annoyed a quiet harmless old patient. It is a relief to everyone that he has been removed as his conversation was continually turning on suicides, post mortems, abduction \& similar cases. Another favourite topic was asylums \& lunatics. ${ }^{173}$

One motivation to maintain a sense of social decorum in the asylum was to prepare patients for their return to the social circles they had previously inhabited. Richard P.F., a twenty-eight-year-old solicitor, was sent to Bloomfield by his father after failing to behave appropriately in the family home: 'when there he sat in the hall, said he was too bad to go upstairs, would not shake hands with anyone'. ${ }^{174}$ Similarly, a Hampstead patient, Henry O.B., was described as having been 'formerly painfully polite now he will not raise his hat to a lady'. ${ }^{175}$ Any breaches of the code of behaviour in public spaces posed serious problems and embarrassment for the relatives of the mentally ill. ${ }^{176}$ This was certainly the 
case for the relatives of Annie Elizabeth W., a single, twenty-eight-yearold 'ladylike little woman', whom the physician at Bloomfield found 'quiet and pleasant to talk to'. He noted:

I believe she thought she was married to some man in her neighbourhood - a preacher, and used to follow him about and went to him in a meeting and put arms around him, causing scandal.

Annie reportedly believed that 'her only prospect is of marrying this man'. She was sent away from home 'for a change' but was eventually committed to Bloomfield by her father. ${ }^{177}$ The relatives of another Bloomfield patient, Cecil W.W., were also troubled by his behaviour, stating that 'before coming here he had been inclined to talk very indecently in the presence of ladies'. While a patient, he escaped and returned to a house where he used to lodge and 'frightened the woman in it by laughing and strange behaviour'. ${ }^{178}$ Cecil's committal to Bloomfield, following this 'indecorous' behaviour, contradicts McCarthy's assumption, in her study of gender ideology and committal to the Enniscorthy asylum, that men's sexual urges were viewed as the fault of women. ${ }^{179}$

Inextricably linked to social decorum was patients' clothing and appearance. Patients and especially women were expected to be neat and tidy in dress and personal habits. ${ }^{180}$ As discussed in Chap. 3, in the 1870s one Richmond paying patient was refused permission to wear his own clothes in the asylum, although presumably this changed under Norman's reign. By the 1890s, Richmond paying patients were photographed wearing their own outfits. Figure 7.2 shows one such patient, Rebecca B. While it is possible that Rebecca was allowed to dress in her own clothes only for this photograph ${ }^{181}$ her depiction in the case notes as being 'fantastically dressed. Wears white shoes with black tape rosettes' suggests otherwise. ${ }^{182}$

Wynter has argued that at the Staffordshire county asylum, which catered for patients from various social classes, "clothing was woven into virtually every aspect of "life inside" during the first half of the nineteenth century', including dress, restraint, laundry and yarn. ${ }^{183}$ At Staffordshire, clothing was the primary purchase of the wealthy and Wynter contends that 'for the rich, dress enabled participation in societal norms and the wider world'. ${ }^{184}$ Patients in Bloomfield and Stewarts also purchased new clothing: Stanley accompanied Thomas S.W. into town 
Fig. 7.2 Photograph of Rebecca B., female paying patient, Richmond district asylum, undated. Appended to 'Female Case Book, 1897-1898', (GM, Richmond District Lunatic Asylum, attached to pp. 337-338)

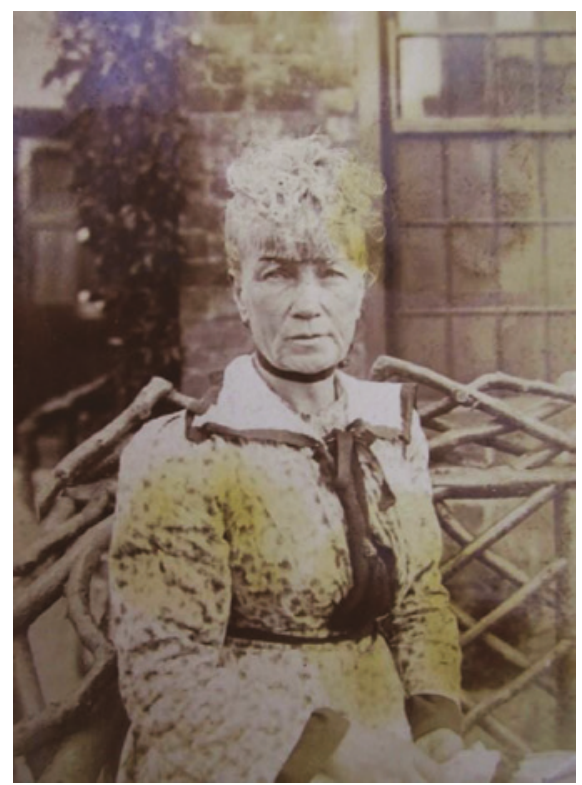

to order a new suit of clothes, while Stewarts patient, George J., was also allowed into town to purchase clothing. ${ }^{185}$

Nineteenth-century asylum doctors often measured mental stability against patient's attire or general appearance. For instance, Andrews has demonstrated the relationship doctors perceived between nakedness and insanity, while patients who did not take care over their appearance were considered irrational and neglectful of the self. ${ }^{186}$ Patients who stripped their clothes were deemed completely unacceptable at Bloomfield. When David S. became excited and 'gave liberty to his unruly member in the most disgraceful manner', Stanley proposed to have him sent directly to the padded-room but could not as it was already occupied by a female patient. Instead, he was sent to his room. ${ }^{187}$ At Stewarts, Anna D.S. was reported to need a special attendant because she frequently took off her clothes. ${ }^{188}$

As part of his programme of reform at Richmond, Norman encouraged patients to make stylish individual clothes for themselves to promote their self-esteem. ${ }^{189}$ This freedom was also apparent in voluntary asylums. When, in 1864, Bloomfield patient David S. decided he no 
longer required the services of the visiting barber and 'most strongly declared he would have his hair to grow both on the upper and lower part of his face', Stanley simply decided to observe whether the patient would continue 'firm in his word'. ${ }^{190}$ When the barber arrived the following day, David went out for a walk and would not allow himself to be shaved. ${ }^{191}$ On another occasion, the same patient decided to adopt a far more outlandish appearance:

Took a strange notion to have his whiskers shaved off and also pierced his ears for earrings to make himself a female. He has written orders for a crinoline and for several changes of silk dresses. ${ }^{192}$

This 'wild notion' was entertained until one of his ears became swollen and inflamed and Duke's attention had to be called to it. Despite David's protests, the threads he had used to keep the puncture open were eventually removed and the ear healed. The extent to which asylum authorities did not wish to interfere in the patient's appearance or behaviour, even in cases where it breached conventional norms, is clear and Stanley was evidently relieved to report that 'the patient seems to have engendered no bad feeling towards any of us for having interfered in the matter'. ${ }^{193}$

At St John of God's, O'Connell often commented on the clothing and general appearance of the male patients. ${ }^{194} \mathrm{He}$ described James McL 'as slovenly and unkempt as ever ... never wears a coat-only a thin shirt and a "sweater" woollen jacket over it, and these he does not keep buttoned and tidy ... wears no hat, and often his shirt is hanging out over his trousers'. ${ }^{195}$ Neat and tidy dress was considered essential and patients who removed their clothes were sometimes put in a lock suit. ${ }^{196}$ Similarly, John Eustace Neilson described Hampstead patient Henry O'B. as being 'foolish in dress' ${ }^{197}$ At Stewarts, patients were encouraged to dress well. When Alice Julia B.'s mother sent her a new skirt, she was 'told she should wear it', although unfortunately she tore it up. ${ }^{198}$ Physicians judged patients in accordance with contemporary fashions and what they considered normal. ${ }^{199}$ For example, Elizabeth A. was reported as being 'rather fantastic in her dress, fond of decorations which are outré. Is silly in appearance and conversation'. ${ }^{200}$ Robert Charles A. was described as being 'careless in dress', while Jane Thomasina J's progress was apparently mapped against her appearance: 'Seems gayer ... Tends to more personal decoration ... Is most demented. Has cut her hair does 
not know why'. ${ }^{201}$ Joshua S.B., meanwhile, threw away his 'collar and tie frequently, believing he is not allowed to wear them'. He was described as being 'eccentric doing queer things' such as wearing 'his shirt back to front' and not 'wearing a tie and so on acting under high orders from a distance'. ${ }^{202}$ Charles L. 'thinks he is a King. Walks around the grounds with a regal stride. His cap turned inside out to imitate a crown. His umbrella over his shoulders and his rug draped artistically from his shoulders'. ${ }^{203}$

\section{CONCLUSION}

This chapter has expanded on the work of Beveridge and Cox on experiences of asylum life. While both scholars have emphasised the influence of social class and status on patient experiences, this study has shown that these factors were especially significant among paying patients in Ireland's district asylums. ${ }^{204}$ We have also seen how class identity influenced patients' expectations of their care and treatment, while simultaneously colouring their carers' expectations of their behaviour. In particular, accommodating new social classes in district asylums spawned changes in the social environment. The influx of paying patients who anticipated privileges beyond those permitted presented managerial challenges for their carers. This group was mindful of maintaining their class identity while housed in institutions intended for and accommodating primarily pauper patients. As Chaps. 3 and 4 have shown, this cohort was also more precariously positioned socially, a factor that only served to fuel their social apprehensions. Some paying patients therefore had expectations of better standards of treatment and criticised asylum conditions, particularly the food they were given.

Paying patients in district asylums were also troubled by mixing with pauper patients. This led to class tensions, which at times culminated in violence towards other patients and staff members. In an era when religious devotion was inextricably bound up with class identity and respectability, these patients were anxious to safeguard their religious identity. Some complained about having to interact with staff and patients of other denominations, expressed concern if told that their mental condition might prevent them from attending mass or church and feared exposure to proselytism. As Walsh has demonstrated, political affiliation was an equally important element of patient identity, evidenced by frequent discussions of key political figures and events. ${ }^{205}$ While there is no 
record of political tensions between paying patients in the district asylums, the political unrest that characterised nineteenth-century Ireland clearly preoccupied some paying patients.

In voluntary and private asylums, conditions were apparently more in line with patients' expectations and relatively few had grievances. Likewise, there is little evidence of class or religious tensions among this cohort. Yet asylum doctors' expectations of respectable and class-appropriate behaviour from their wealthier patients were often frustrated by their regular violent outbursts. In fact, paying patients in the asylums studied evinced higher levels of violence than their pauper counterparts. This reveals that even when families invested large sums of money in asylum care, this did little to protect their relatives from violence. Patients' ill manners and strange dress and appearance also frustrated attempts to maintain harmonious surroundings in the asylum. Although moral therapy remained a dominant ideological framework for late nineteenthcentury asylums and, in many respects, was still viable in the smaller, less crowded voluntary and private asylums, it was often the patients themselves who ultimately disrupted social codes and expectations of respectability.

\section{Notes}

1. Digby (1985, pp. 49-56). See also Scull (1982, pp. 186-253).

2. Finnane (1981, p. 175), Cox (2012, p. 229).

3. Ibid.

4. Cox (2012, p. 218).

5. Beveridge (1998).

6. Beveridge has found similar in Scotland: Ibid.

7. See, for example, Ibid., pp. 443-445.

8. Finnane (1981, pp. 39-40, 201-208), Cox (2012, pp. 207-212).

9. Cherry (1992).

10. Ibid.

11. Finnane (1981, p. 39).

12. Ibid.; Reynolds (1992, pp. 184-185). For more on Norman's reforms see Kelly (2016, pp. 111-114).

13. Reynolds (1992, p. 186).

14. Annual Report of the State of the Retreat (Dublin 1862), p. 8.

15. The Stewart Institution and Asylum Report (Dublin 1881), p. 14.

16. Annual Report of the State of the Retreat (Dublin 1865), p. 12. 
17. Edward Hyde, Notice of Particulars (FHL, Bloomfield Records, 17 \& 18 Dec. 1863).

18. Ibid., 19 Dec. 1863.

19. For example, Edward Hyde, Notice of Particulars (FHL, Bloomfield Records, 16 Jan. 1866).

20. Ibid., 30 Jan. 1866.

21. Annual Report of the State of the Retreat (Dublin 1867), p. 8.

22. For example, see Finnane's discussion of the contrasting therapeutic regimes in the Maryborough and Carlow asylums in the 1830s: Finnane (1981, p. 40).

23. For more on moral treatment and moral management, see Digby (1985, pp. 33-87).

24. Case Book 1889-1900 (Stewarts, Patient Records, pp. 108, 67).

25. Ibid., p. 46.

26. Ibid., p. 127.

27. Case Book (FHL, Bloomfield Records, p. 10).

28. Male Case Book, 1891-1892 (GM, Richmond District Lunatic Asylum, pp. 37-39).

29. Minute Book No. 12, 1867-1872 (NAI, Richmond District Lunatic Asylum, p. 285).

30. Male Case Book, 1887-1888 (GM, Richmond District Lunatic Asylum, p. 202; letter appended p. 203).

31. Office of Lunatic Asylums to Ennis District Lunatic Asylum, 4 Jun. 1891 (CCA, Our Lady's Hospital, OLl/7 Letter 1727).

32. Office of Lunatic Asylums to R.P. Gelston, 8 June 1891 (CCA, Our Lady's Hospital, OLl/7 Letter 1727a).

33. Cox $(2012$, pp. 210, 218).

34. Finnane (1981, p. 204).

35. Beveridge (1998, p. 432).

36. Cox (2012, p. 211).

37. Clinical Record Volume No. 4 (WCC, St Senan's Hospital, Enniscorthy, p. 360).

38. Clinical Record Volume No. 5 (WCC, St Senan's Hospital, Enniscorthy, p. 186).

39. Female Case Book, 1857-1887 (GM, Richmond District Lunatic Asylum, p. 528).

40. Beveridge (1998, p. 440).

41. Female Case Book 1897-1888 (GM, Richmond District Lunatic Asylum, pp. 533, 536).

42. Female Case Book, 1889-1890 (GM, Richmond District Lunatic Asylum, p. 607). 
43. Male Case Book, 1894-1895 (GM, Richmond District Lunatic Asylum, p. 235).

44. Clinical Records Volume No. 4 (WCC, St Senan's Hospital, Enniscorthy, pp. 391-392).

45. Female Case Book, 1890-1891 (GM, Richmond District Lunatic Asylum, pp. 279, 294).

46. Female Case Book, 1892-1893 (GM, Richmond District Lunatic Asylum, pp. 530-532, 539).

47. Male Case Book, 1888-1889 (GM, Richmond District Lunatic Asylum, p. 777).

48. 'Female Case Book, 1900-1901' (GM, Richmond District Lunatic Asylum, pp. 773, 775).

49. Clarkson and Crawford (2001, pp. 105-107).

50. Clinical Record Volume No. 3 (WCC, St Senan's Hospital, Enniscorthy, p. 318).

51. Clinical Record Volume No. 6 (WCC, St Senan's Hospital, Enniscorthy, p. 30).

52. Ibid., p. 216.

53. Medical Superintendent's Memorandum Books, 1868-1889 (WCC, St Senan's Hospital, Enniscorthy, p. 138).

54. Female Case Book, 1893-1894 (GM, Richmond District Lunatic Asylum, pp. 261, 320, 323).

55. Male Case Book, 1892-1893 (GM, Richmond District Lunatic Asylum, p. 483$)$.

56. Male Case Book, 1898 (GM, Richmond District Lunatic Asylum, appended to p. 761 ).

57. Female Case Book, 1891-1892 (GM, Richmond District Lunatic Asylum, p. 460).

58. Clinical Record Volume No. 3 (WCC, St Senan's Hospital, Enniscorthy, p. 336).

59. Andrews (1998, p. 266).

60. Male Case Book, 1892-1893 (GM, Richmond District Lunatic Asylum, pp. 338-339).

61. Cox (2012, pp. 211-212).

62. The Thirty-Ninth Report on the District, Criminal, and Private Lunatic Asylums in Ireland, H.C. 1890, p. 92.

63. Ibid., p. 93.

64. Malcolm (1989, p. 134).

65. The Stewart Institution and Asylum Report (Dublin 1890), p. 21.

66. The Stewart Institution and Asylum Report (Dublin 1892), p. 24.

67. Annual Reports of the State of the Retreat.

68. The Stewart Institution and Asylum Report (Dublin 1871), p. 13. 
69. The Stewart Institution and Asylum Report (Dublin 1898), p. 24.

70. Annual Report of the State of the Retreat (Dublin 1855), p. 8.

71. Edward Hyde, Notice of Particulars (FHL, Bloomfield Records, 3 June 1864).

72. Ibid., 28 Jan. 1864.

73. Case Book (FHL, Bloomfield Records, p. 37).

74. Ibid., p. 59.

75. For example, Case Book 1889-1900 (Stewarts, Patient Records, pp. 73, 174).

76. Case Book (FHL, Bloomfield Records, pp. 39, 72).

77. Casebook Two (SJOGH, Patient Records, p. 54).

78. Ibid., p. 29.

79. Ibid.

80. Beveridge had found similar issues among patients in the Morningside asylum in Edinburgh. Beveridge (1998, p. 50).

81. Clinical Record Volume No. 7 (WCC, St Senan's Hospital, Enniscorthy, p. 44); Clinical Record Volume No. 4 (WCC, St Senan's Hospital, Enniscorthy, p. 386).

82. Female Case Book, 1899-1900 (GM, Richmond District Lunatic Asylum, p. 636).

83. Clinical Record Volume No. 6 (WCC, St Senan's Hospital, Enniscorthy, p. 120).

84. Female Case Book, 1889-1890 (GM, Richmond District Lunatic Asylum, p. 460).

85. Beveridge (1998, p. 442).

86. Finnane (1981, pp. 179-180).

87. Cox (2012, p. 203). For the English context, see Melling and Forsythe (2006, p. 57).

88. Female Case Book, 1889-1890 (GM, Richmond District Lunatic Asylum, p. 430).

89. Female Case Book, 1897-1898 (GM, Richmond District Lunatic Asylum, p. 340); Female Case Book, 1898-1899 (GM, Richmond District Lunatic Asylum, pp. 852, 868).

90. Female Case Book, 1895-1897 (GM, Richmond District Lunatic Asylum, p. 26).

91. Female Case Book, 1892-1893 (GM, Richmond District Lunatic Asylum, p. 848).

92. Clinical Record Volume No. 7 (WCC, St Senan's Hospital, Enniscorthy, p. 43).

93. Ibid., p. 44.

94. Ibid., p. 57.

95. Reynolds (1992, p. 88), Cox (2012, p. 206). 
96. Hampstead Casebook 1890s (Highfield Hospital Group, Hampstead and Highfield Records, p. 24).

97. Casebook Two (SJOGH, Patient Records, p. 6).

98. Ibid., p. 26.

99. Ibid., p. 30.

100. Ibid., p. 45.

101. Early Hampstead Casebook 1840s (Highfield Hospital Group, Hampstead and Highfield Records, p. 14).

102. Hampstead Casebook 1890s (Highfield Hospital Group, Hampstead and Highfield Records, p. 46).

103. Digby (1985, p. 54).

104. Case Book (FHL, Bloomfield Records, p. 64).

105. Case Book 1889-1900 (Stewarts, Patient Records, p. 175).

106. Ibid., p. 137.

107. Ibid., pp. 27, 137.

108. Davidoff and Hall (1987, p. 76).

109. Ibid.

110. Comerford (1989).

111. Cox (2012, pp. 214-215).

112. Ibid.

113. Prior and Griffiths (2012).

114. Ibid., pp. 169, 182.

115. Walsh (1999, pp. 228-233).

116. Clinical Record Volume No. 7 (WCC, St Senan's Hospital, Enniscorthy, p. 465). Drapes was on the Synod of his diocese and secretary of the local choir union for 30 years. Kelly (2016, p. 95).

117. Clinical Record Volume No. 5 (WCC, St Senan's Hospital, Enniscorthy, pp. 410-411).

118. Female Case Book, 1892-1893 (GM, Richmond District Lunatic Asylum, pp. 769, 772).

119. Male Case Book, 1882-1883 (GM, Richmond District Lunatic Asylum, p. 50$)$.

120. Female Case Book, 1898-1899 (GM, Richmond District Lunatic Asylum, pp. 489, 491).

121. Annual Report of the State of the Retreat (Dublin 1863), p. 12.

122. Report into the State of Lunatic Asylums, Part II, p. 161.

123. Forty-Fourth Report of the Inspectors of Lunatics (Ireland), H.C. 1895, p. 170.

124. The Stewart Institution and Asylum Report (Dublin 1883), p. 21.

125. The Stewart Institution and Asylum Report (Dublin 1896), p. 24.

126. Case Book 1889-1900 (Stewarts, Patient Records, pp. 87, 161).

127. Ibid., p. 150. 
128. Edward Hyde, Notice of Particulars (FHL, Bloomfield Records, 6 Jan. 1868).

129. Daly $(1984$, p. 124).

130. Walsh (1999, p. 223).

131. Drapes (1894).

132. As Cox has observed, 'when Drapes was writing in 1894, the country had gone through two decades of turbulent and disruptive events', including political agitation over land ownership and tenant's rights and the Home Rule movement. Cox (2012, pp. 63-64).

133. Female Case Book, 1888-1889 (GM, Richmond District Lunatic Asylum, pp. 530-531).

134. Male Case Book, 1890-1891 (GM, Richmond District Lunatic Asylum, p. 921); Katharine O'Shea was best known for her love affair with Parnell during her marriage to Captain William O'Shea, a Catholic Nationalist MP for Galway borough. This affair, and Katharine's subsequent divorce, created a very public scandal and had negative implications for Parnell's political career. Katharine and Parnell were married in 1891.

135. Female Case Book, 1890-1891 (GM, Richmond District Lunatic Asylum, pp. 445, 450).

136. Female Case Book, 1891-1892 (GM, Richmond District Lunatic Asylum, p. 83); Female Case Book, 1898-1899 (GM, Richmond District Lunatic Asylum, p. 247).

137. Female Case Book, 1897-1898 (GM, Richmond District Lunatic Asylum, p. 535).

138. Malcolm (1989, pp. viii-x, 243-245).

139. Ibid., pp. $x, 243$. William Saunders Hallaran established the Cittadella private asylum in Cork. For more, see Kelly (2008, pp. 79-84).

140. Case Book (FHL, Bloomfield Records, p. 22).

141. For example, Cox (2012), Finnane (1981), Walsh (2001).

142. Cox (2012).

143. See Cox (2012), Finnane (1981, 1985), Malcolm (1999, 2003), Walsh (2001, 2004).

144. Lunacy (Ireland) Act, 1867, 30 \& 31 Vic., c. 117, s. 10. For further explanation of district asylum admission procedures see Cox (2012, pp. 73-96).

145. Finnane (1981, p. 161).

146. Cox (2012, p. 220).

147. Ibid.

148. Case Book (FHL, Bloomfield Records, p. 11).

149. Ibid., p. 57.

150. Ibid., p. 63. 
151. See, for example, Ibid., pp. 45, 58; Case Book 1889-1900 (Stewarts, Patient Records, pp. 5, 46, 49, 56, 77, 84, 95, 99, 115, 119, 135, 142, $144,161,175)$.

152. For example, Case Book 1889-1900 (Stewarts, Patient Records, pp. 11, $82,77,94,49,113,144)$.

153. The Stewart Institution and Asylum Report (Dublin 1894), p. 20.

154. For example, Case Book 1889-1900 (Stewarts, Patient Records, pp. $141,142,143,175)$.

155. Highfield Casebook (Highfield Hospital Group, Hampstead and Highfield Records, p. 21).

156. Casebook Two (SJOGH, Patient Records, p. 19).

157. Ibid., p. 40.

158. Case Book 1889-1900 (Stewarts, Patient Records, p. 100).

159. Ibid., pp. 94, 75 .

160. Cox (2012, p. 206).

161. Edward Hyde, Notice of Particulars (FHL, Bloomfield Records, 28 Dec. 1863).

162. Ibid., 30 Dec. 1863.

163. Ibid., I Jan. 1864.

164. Malcolm (1989, p. 209).

165. Case Book (FHL, Bloomfield Records, pp. 38, 45, 71).

166. For example, Ibid., p. 27.

167. Elaine Showalter has also found this in nineteenth-century Britain: see Showalter (1986).

168. Case Book 1889-1900 (Stewarts, Patient Records, p. 167).

169. Ibid., p. 118. For other examples see Ibid., pp. 32, 44.

170. For example, Ibid., p. 44.

171. Case Book (FHL, Bloomfield Records, p. 70).

172. Ibid.

173. Hampstead Casebook 1890s (Highfield Hospital Group, Hampstead and Highfield Records, p. 12).

174. Case Book (FHL, Bloomfield Records, p. 80).

175. Hampstead Casebook 1890s (Highfield Hospital Group, Hampstead and Highfield Records, p. 16).

176. Suzuki (2001, pp. 121-122).

177. Case Book (FHL, Bloomfield Records, p. 62).

178. Ibid., pp. 73,75 .

179. McCarthy $(2004$, p. 122).

180. Ibid., p. 131.

181. See Gilman (1996).

182. Female Case Book, 1897-1898 (GM, Richmond District Lunatic Asylum, p. 340). 
183. Wynter (2010, p. 41).

184. Ibid., pp. 41-42.

185. Edward Hyde, Notice of Particulars (FHL, Bloomfield Records, 8 Apr. 1864); Case Book 1889-1900 (Stewarts, Patient Records, p. 72).

186. Andrews (2007).

187. Edward Hyde, Notice of Particulars (FHL, Bloomfield Records, 18 Jan. 1864).

188. Case Book 1889-1900 (Stewarts, Patient Records, p. 88).

189. Reynolds (1992, pp. 183-184).

190. Edward Hyde, Notice of Particulars (FHL, Bloomfield Records, 12 Feb. 1864).

191. Ibid., 13 Feb. 1864.

192. Ibid., 6 Dec. 1865.

193. Ibid., 13 Dec. 1865.

194. For example, Casebook Two (SJOGH, Patient Records, pp. 39, 53, 22).

195. Ibid., p. 15.

196. For example, Ibid., pp. 15, 24.

197. Hampstead Casebook 1890s (Highfield Hospital Group, Hampstead and Highfield Records, p. 32).

198. Case Book 1889-1900 (Stewarts, Patient Records, p. 29).

199. This was not exclusive to Stewart's. See Showalter (1982, p. 84). Malcolm has noted similar concerns regarding patients' appearance in $\mathrm{St}$ Patrick's Hospital. See Malcolm (1989, p. 169).

200. Case Book 1889-1900 (Stewarts, Patient Records, p. 157).

201. Ibid., pp. 122, 35, 44.

202. Ibid., pp. $59,25$.

203. Ibid., p. 26.

204. Cox (2012, p. 218); Beveridge (1998, pp. 442-453).

205. Walsh (1999, p. 223).

\section{REFERENCES}

Andrews, Jonathan. 'Case Notes, Case Histories and the Patient's Experience of Insanity at Gartnaval Royal Asylum, Glasgow, in the Nineteenth Century.' Social History of Medicine 11, no. 2 (1998): 255-281.

Andrews, Jonathan. 'The (Un)dress of the Mad Poor in England, c. 16501850.' Parts I and II. History of Psychiatry 18, no. I (2007): 5-24; 18, no. 2 (2007): 131-156.

Beveridge, Allan. 'Life in the Asylum: Patient's Letters from Morningside, 18731908.' History of Psychiatry 9 (1998): 431-469. 
Cherry, Charles L. 'An Anglo-Irish Connection: York Retreat and Bloomfield Hospital.' Paper presented at the conference of Quaker Historians and Archivists, Willmington College, Ohio, USA, June 1992.

Clarkson, L. A. and E. Margaret Crawford. Feast and Famine: A History of Food and Nutrition in Ireland, 1500-1920. Oxford and New York: Oxford University Press, 2001.

Comerford, R. V. 'Ireland 1850-1870: Post-Famine and Mid-Victorian.' In A New History of Ireland V: Ireland under the Union, I, 1801-1870, edited by W. E. Vaughan, 371-385. Oxford: Oxford University Press, 1989.

Cox, Catherine. Negotiating Insanity in the Southeast of Ireland 1830-1900. Manchester: Manchester University Press, 2012.

Daly, Mary E. Dublin, The Deposed Capital: A Social and Economic History, 1860-1914. Cork: Cork University Press, 1984.

Davidoff, Leonore and Catherine Hall. Family Fortunes: Men and Women of the English Middle Class 1780-1850. Chicago: University of Chicago Press, 1987.

Digby, Anne. Madness, Morality and Medicine: A Study of the York Retreat, 17961914. Cambridge: Cambridge University Press, 1985.

Drapes, Thomas. 'On the Alleged Increase of Insanity in Ireland.' Journal of Mental Science 40 (1894): 519-543.

Finnane, Mark. Insanity and the Insane in Post-Famine Ireland. London: Croom Helm, 1981.

Finnane, Mark. 'Asylums, Families and the State.' History Workshop Journal 20, no. 1 (1985): 134-148.

Gilman, Sander. Seeing the Insane. Lincoln: University of Nebraska Press, 1996.

Kelly, Brendan D. 'Dr. William Saunders Hallaran and Psychiatric Practice in Nineteenth-Century Ireland.' Irish Journal of Medical Science, 117, no. 1 (2008): 79-84.

Kelly, Brendan. Hearing Voices: The History of Psychiatry in Ireland. Newbridge: Irish Academic Press, 2016.

Malcolm, Elizabeth. Swift's Hospital: A History of St. Patrick's Hospital, Dublin, 1746-1989. Dublin: Gill and Macmillan, 1989.

Malcolm, Elizabeth. 'The House of Strident Shadows: The Asylum, the Family and Emigration in Post-Famine Rural Ireland.' In Medicine, Disease and the State in Ireland 1650-1940, edited by Elizabeth Malcolm and Greta Jones, 177-195. Cork: Cork University Press, 1999.

Malcolm, Elizabeth. "Ireland's Crowded Madhouses": The Institutional Confinement of the Insane in Nineteenth- and Twentieth-Century Ireland.' In The Confinement of the Insane: International Perspectives, 1800-1965, edited by Roy Porter and David Wright, 315-333. Cambridge: Cambridge University Press, 2003.

McCarthy, Áine. 'Hearths, Bodies and Minds: Gender Ideology and Women's Committal to Enniscorthy Lunatic Asylum, 1916-1925.' In Irish Women's 
History, edited by Alan Hayes and Diane Urquhart, 115-136. Dublin: Irish Academic Press, 2004.

Melling, Joseph and Bill Forsythe. The Politics of Madness: The State, Insanity and Society in England, 1845-1814. London and New York: Routledge, 2006.

Prior, Pauline M. and David V. Griffiths. "The "Chaplaincy Question" at Belfast District Asylum, 1834-1870.' In Asylums, Mental Health Care and the Irish: Historical Studies, 1800-2010, edited by Pauline M. Prior, 167-184. Dublin and Portland: Irish Academic Press, 2012.

Reynolds, Joseph. Grangegorman: Psychiatric Care in Dublin Since 1815. Dublin: Institute of Public Administration, 1992.

Scull, Andrew. Museums of Madness: The Social Organisation of Insanity in Nineteenth-Century England. Harmondsworth: Penguin, 1982.

Showalter, Elaine. The Female Malady: Women Madness and Culture in England, 1830-1980. New York: Pantheon Book, 1986.

Suzuki, Akihito. 'Enclosing and Disclosing Lunatics within the Family Walls: Domestic Psychiatric Regime and the Public Sphere in Early NineteenthCentury England.' In Outside the Walls of the Asylum: The History of Care in the Community, 1750-2000, edited by Peter Bartlett and David Wright, 115132. London: Athlone Press, 2001.

Walsh, Oonagh. "“The Designs of Providence": Race, Religion and Irish Insanity.' In Insanity, Institutions and Society, 1800-1914: A Social History of Madness in Comparative Perspective, edited by Joseph Melling and Bill Forsythe, 223-242. London and New York: Routledge, 1999.

Walsh, Oonagh. 'Lunatic and Criminal Alliances in Nineteenth-Century Ireland.' In Outside the Walls of the Asylum: The History of Care in the Community 1750-2000, edited by Peter Bartlett and David Wright, 132-152. London: Athlone Press, 2001.

Walsh, Oonagh. 'Gender and Insanity in Nineteenth-Century Ireland.' In Sex and Seclusion, Class and Custody: Perspectives on Gender and Class in the History of British Psychiatry, edited by Jonathan Andrews and Anne Digby, 69-93. Amsterdam and New York: Rodopi, 2004.

Wynter, Rebecca. 'Good in all Respects: Appearance and Dress at Staffordshire County Lunatic Asylum, 1818-1854.' History of Psychiatry 22, no. I (2010): $40-57$. 
Open Access This chapter is licensed under the terms of the Creative Commons Attribution 4.0 International License (http://creativecommons.org/licenses/ by $/ 4.0 /$ ), which permits use, sharing, adaptation, distribution and reproduction in any medium or format, as long as you give appropriate credit to the original author(s) and the source, provide a link to the Creative Commons license and indicate if changes were made.

The images or other third party material in this chapter are included in the chapter's Creative Commons license, unless indicated otherwise in a credit line to the material. If material is not included in the chapter's Creative Commons license and your intended use is not permitted by statutory regulation or exceeds the permitted use, you will need to obtain permission directly from the copyright holder.

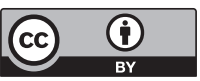

